"This is the peer reviewed version of the following article: ChemSusChem 2016, 9, 1304-1311, which has been published in final form at DOI: $10.1002 /$ cssc.201600238. This article may be used for non-commercial purposes in accordance with Wiley Terms and Conditions for Self-Archiving published at http://olabout.wiley.com/WileyCDA/Section/id-820227.html." 


\title{
Catalytic Coupling of Carbon Dioxide with Terpene Scaffolds: Access to Challenging Bio-Based Organic Carbonates
}

\author{
Giulia Fiorani, ${ }^{* a]}$ Moritz Stuck, ${ }^{[a]}$ Carmen Martín, ${ }^{[a]}$ Marta Martínez Belmonte, ${ }^{[a]}$ Eddy Martin, ${ }^{[a]}$ Eduardo \\ C. Escudero-Adán ${ }^{[a]}$ and Arjan W. Kleij ${ }^{*[a][b]}$
}

\begin{abstract}
The challenging coupling of highly substituted terpene oxides and carbon dioxide into bio-based cyclic organic carbonates catalyzed by $\mathrm{Al}$ (aminotriphenolate) complexes, is reported herein. Both acyclic as well as cyclic terpene oxides were used as coupling partners, showing distinct reactivity/selectivity behavior. Whereas cyclic terpene oxides showed excellent chemo-selectivity towards the organic carbonate product, acyclic substrates exhibited poorer selectivities due to concomitant epoxide rearrangement reactions and the formation of undesired oligo/polyether side products. Considering the challenging nature of these coupling reactions, the isolated yields of the targeted bio-carbonates are reasonable and in most cases in the range $50-60 \%$. The first crystal structures of tri-substituted terpene based cyclic carbonates are reported and their stereoconnectivity suggests that their formation proceeds through a double inversion pathway.
\end{abstract}

\section{Introduction}

The conversion of carbon dioxide $\left(\mathrm{CO}_{2}\right)$ into useful organic products is a prominent strategy towards the valorization of this renewable carbon-based feed stock. ${ }^{[1]}$ Despite the exciting progress in the area of catalytic conversion of $\mathrm{CO}_{2}$ into various products such as polymers, ${ }^{[2]}$ synthetic fuels ${ }^{\left[{ }^{[3]}\right.}$ and finechemicals, ${ }^{[4]}$ a remaining challenge in the area of $\mathrm{CO}_{2}$ conversion is represented by the limited number of chemical functionalities that can be derived from this $\mathrm{C}_{1}$ building block. So far, most efforts have been devoted to $\mathrm{CO}_{2}$ conversion via reductive and nonreductive coupling chemistry. Within the latter category, $\mathrm{CO}_{2}$ is incorporated into an organic substrate without affecting the oxidation state of the carbon center, and the most prominent among this type of transformations is the formation of organic carbonates using epoxides as reaction partners. ${ }^{[5]}$

The catalytic coupling of epoxides and $\mathrm{CO}_{2}$ is an atomefficient reaction that has been well-studied and ditto developed over the years, with important contributions to solve key

[a] Dr. G. Fiorani, M. Stuck, Dr. C. Martín, Dr. M. Martínez Belmonte Dr. E. Martin, E. C. Escudero-Adán, Prof. Dr. A. W. Kleij Institute of Chemical Research of Catalonia (ICIQ)

The Barcelona Institute of Science and Technology Av. Països Catalans 16, 43007 Tarragona (Spain) E-mail: akleii@iciq.es; gfiorani@iciq.es

[b] Prof. Dr. A. W. Kleij

Catalan Institute of Research and Advanced Studies (ICREA) Pg. Lluís Companys 23, 08010 Barcelona (Spain)

Supporting information for this article is given via a link at the end of the document. challenges associated to this process, including enhanced reactivity/selectivity, ${ }^{[6]}$ improved overall sustainability, ${ }^{[7]}$ and the development of commercially attractive, recyclable catalysts. ${ }^{[8]}$ However, there are still important open challenges in this specific area of research, including the limited number of substrates that can be used due to the lack of efficient catalytic strategies for their coupling. Highly substituted epoxides (1,3-dioxolan-2-ones) including those with a 4,5-disubstitution ${ }^{[9]}$ and $4,4^{\prime}, 5$ trisubstitution ${ }^{[10]}$ remain challenging reaction partners despite the presence of such patterns in many naturally occurring plant based organic carbonates (Figure 1). ${ }^{[11]}$

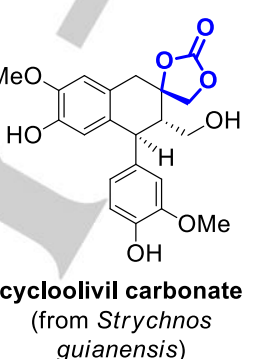
guianensis)

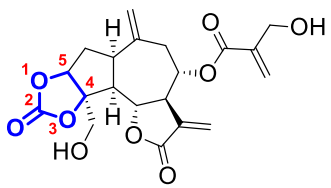

Hololeucin (from Centaurea hololeuca)

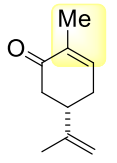<smiles>C=C(C)[C@H]1CC=C(C)CC1</smiles><smiles>C=CC(C)(O)CCC=C(C)C</smiles>

limonene

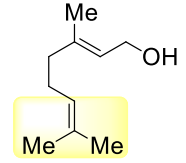

geraniol
Figure 1. Top: naturally occurring organic carbonates based on complex scaffolds. The carbonate unit is marked in blue. Below: some representative terpene scaffolds with similar di- and tri-substituted alkene units highlighted in yellow.

We have recently become interested in the use of renewable feed stocks such as terpenes as substrates for $\mathrm{CO}_{2}$ conversion. ${ }^{[12]}$ Terpenes, including limonene (Figure 1), ${ }^{[10,13 a]}$ have increasingly found applications in polymer science and sustainable materials. ${ }^{[13 b]}$ The formation of cyclic organic carbonates from terpene scaffolds ultimately results in 100\% bio-derived compounds with relatively unexplored potential, ${ }^{[14]}$ and we thus set out to develop an efficient catalytic process for their formation. Here we describe the $\mathrm{Al}(\mathrm{III})$ catalysed coupling between $\mathrm{CO}_{2}$ and 
both cyclic and acyclic terpene oxides affording new bio-based carbonates. The first crystal structures of terpene derived carbonates are also presented and the observed stereoconnectivity is linked to a double inversion pathway in the coupling between the oxirane precursors and $\mathrm{CO}_{2}$.

\section{Results and Discussion}

Terpene Carbonates with bicyclic structures. We first devoted our attention to the conversion of 1-methylcyclohexene oxide 1a to the corresponding cyclic carbonate product $\mathbf{1 b}$ via $\mathrm{CO}_{2}$ insertion. Up to $70^{\circ} \mathrm{C}$ we were unable to detect any formation of cyclic carbonate $\mathbf{1 b}$. This is in line with a previously reported density functional theory analysis of the coupling between limonene oxide (LO, a structurally related trisubstituted oxirane) and $\mathrm{CO}_{2}$, showing that the kinetic barrier towards cyclic carbonate formation (via backbiting) is comparatively high to the one associated to chain propagation.

Table 1. Screening of reaction conditions in the coupling of methylcyclohexene oxide $\mathbf{1 a}$ and $\mathrm{CO}_{2}$ to afford cyclic carbonate $\mathbf{1 b}$. $^{\text {[a] }}$

\begin{tabular}{cccccc} 
& \\
\hline
\end{tabular}

[a] Reaction conditions: 1-methylcyclohexene oxide 1a (5 mmol), MEK (methylethyl ketone, $1.0 \mathrm{~mL}$ ), $p\left(\mathrm{CO}_{2}\right)=1.0 \mathrm{MPa}$ (10 bar). [b] Isolated yield, selectivity for $\mathbf{1 b}$ was $>99 \%$ in all cases determined by ${ }^{1} \mathrm{H}$ NMR. [c] Note that the NMR yield was $75 \%$, in the absence of complex $\mathbf{A}$ the NMR and isolated yield were both $31 \%$ (see entry 3 ). [d] No MEK used.

Indeed, when coupling $\mathrm{LO}$ and $\mathrm{CO}_{2}$ at lower temperatures $\left(40-70^{\circ} \mathrm{C}\right)$ the only product observed was the poly(limonene)carbonate. ${ }^{[12 a]}$ Hence, higher reaction temperatures were probed in order to direct the chemo-selectivity towards the cyclic carbonate product when using 1methylcyclohexene oxide 1a. The substrate 1-methylcyclohexene oxide 1a was taken as a representative terpene model substrate (Table 1). Al(III) aminotriphenolate complexes A-D were used as catalysts together with bis(triphenylphosphine)iminium chloride (PPNCl) as the nucleophilic additive. Although in the presence of the nucleophile only (entries 1-3, Table 1) conversion to $\mathbf{1 b}$ is noted, the addition of a Lewis acid (A-D) substantially improves the overall kinetics, most noteworthy when complex $\mathbf{A}$ is used (entries 5, 9 and 10). As expected, in the absence of PPNCl (entry 4) no conversion was noted. A lower loading of PPNCl (entry 13, $1 \mathrm{~mol} \%$ ) reduced the yield of $\mathbf{1 b}$ to only $14 \%$ showing the requirement for a higher loading of the nucleophile. In the absence of solvent (MEK) virtually no conversion was obtained (see entry 11) underlining the crucial role of this solvent to accommodate appropriate mixing of all reactants. The structure of $\mathbf{1 b}$ was confirmed by $\mathrm{X}$-ray analysis and is depicted in Figure 2.

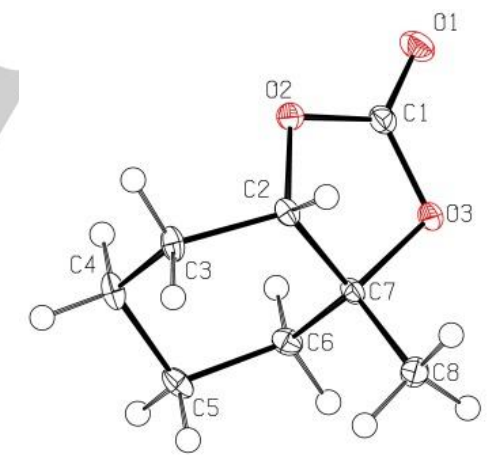

Figure 2. X-ray molecular structure for $\mathbf{1 b}$. Selected bond lengths $(\AA)$ and angles $\left({ }^{\circ}\right)$ for $\mathbf{1 b}$ : $\mathrm{C}(1)-\mathrm{O}(1)=1.1988(18), \mathrm{C}(1)-\mathrm{O}(2)=1.3442(19), \mathrm{C}(1)-\mathrm{O}(3)=$ $1.3487(18) ; \mathrm{O}(2)-\mathrm{C}(1)-\mathrm{O}(3)=111.47(12), \mathrm{O}(1)-\mathrm{C}(1)-\mathrm{O}(2)=124.23(14)$.

With these optimal conditions in hand we decided to investigate a wider scope of trisubstituted carbonates derived from cyclic epoxides based on terpene scaffolds (see Figure 3). Due to the challenging nature of these coupling reactions, conversion of the respective terpene epoxides proceeds slowly and reaction times of $66 \mathrm{~h}$ are typically required (Figure 3). Longer reaction times at $85^{\circ} \mathrm{C}$ did not improve the conversion levels and neither did higher reaction temperatures. ${ }^{[15]}$ We first examined limonene oxide (LO) as a substrate using the best conditions probed for the synthesis of $\mathbf{1 b}$. Whereas pure trans-LO was converted into limonene carbonate $\mathbf{2} \mathbf{b}$ in appreciable conversion $(73 \%)$ and yield $(57 \%)$, the use of the pure cis isomer only led to $4 \%$ yield of cis-3b (by NMR) of its respective carbonate. The extreme sluggish outcome observed for $\mathrm{CO}_{2}$ coupling with the 
above mentioned cis-isomer was confirmed using commercially available LO (a 60:40 trans/cis mixture) 


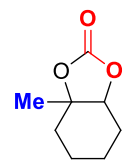

1b: Conv. $75 \%$ Sel. $>99 \%$ Yield: $49 \%$

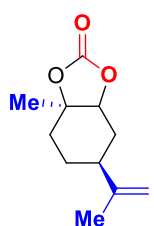

2b: Conv. $73 \%$

Sel. $>99 \%$

Yield: $57 \%$ $d r>99: 1$ (trans)

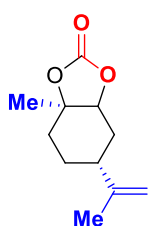

3b: Conv. $4 \%$

Sel. $>99 \%$

$d r>99 \%$ (cis)

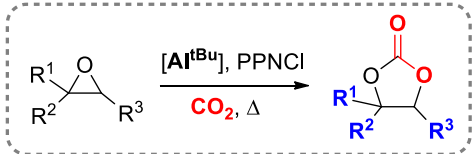

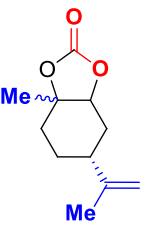

4b: Conv. $60 \%$

Sel. $>99 \%$

Yield: $43 \%$

$d r=4: 96$ (trans)

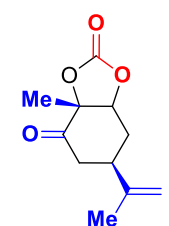

5b: Conv. $80 \%$

Sel. $>99 \%$

Yield $=52 \%$

$d r=20: 80($ cis $)$

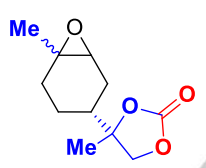

6b: Conv. $90 \%{ }^{[a]}$ Yield: $52 \%$ $d r=48: 52(\mathrm{cis})$

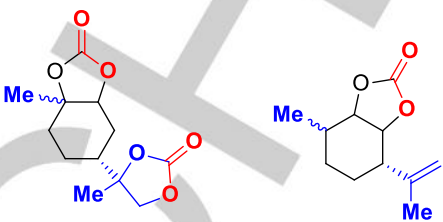

7b: Conv. $92 \%{ }^{[\mathrm{b}]} \quad \mathbf{8 b}:\left[\mathrm{Al}^{\mathrm{Cl}}\right] / \mathrm{TBAB}=0.2 / 5.0 \mathrm{mo} / \%$ Yield: $27 \%$ [c] $d r=80: 20$ (trans) 8b: $\left[\mathrm{Al}^{\mathrm{Cl}}\right] / \mathrm{TBAB}=0.2 / 5.0 \mathrm{mo} \%$
Conv. $68 \% ;$ Yield $=45 \%$ $d r=74: 26^{[\mathrm{d}]}$

Figure 3. Investigated scope for the formation of trisubstituted bicyclic terpene carbonates. Reaction conditions (unless state otherwise): 1.0 mol\% [AltBu], 3.0 mol\% PPNCI, $1.0 \mathrm{~mL}$ MEK, $66 \mathrm{~h}, 85^{\circ} \mathrm{C}, p\left(\mathrm{CO}_{2}\right)^{\circ}=1.0 \mathrm{MPa}$. The diastereo-isomeric ratios (dr values, major isomer indicated) and selectivity towards the carbonate products were also determined by ${ }^{1} \mathrm{H}$ NMR; note that the $d r$ relates to the relative position of both substituents on the cyclohexyl ring. ${ }^{\text {[a] }}$ Conversion relates to total amount of epoxide groups converted to cyclic carbonate ones determined by ${ }^{1} \mathrm{H}$ NMR $\left(\mathrm{CDCl}_{3}\right)$ integration, NMR yield of $6 \mathbf{b}$ was $74 \%$. ${ }^{[b]}$ The $\mathrm{NMR}$ yield of $7 \mathbf{b}$ was $27 \%$ with $24 \%$ of $6 \mathrm{~b}$ being present along with polyether by-product. ${ }^{[c]}$ Reaction performed at $120^{\circ} \mathrm{C}$. [d] The major stereo-isomer assignment was not possible by 1D/2D NMR due to a combination of complex patterns.

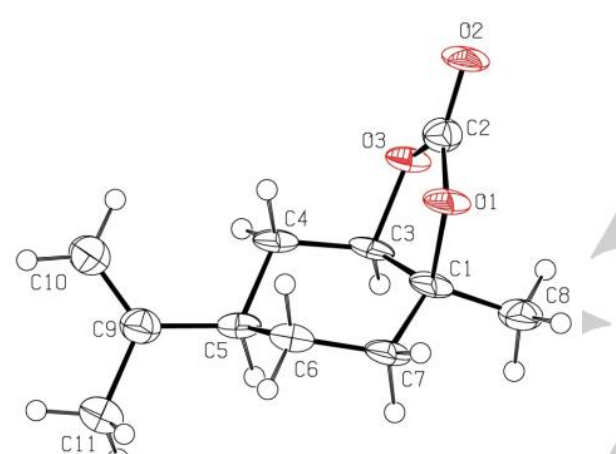

2b

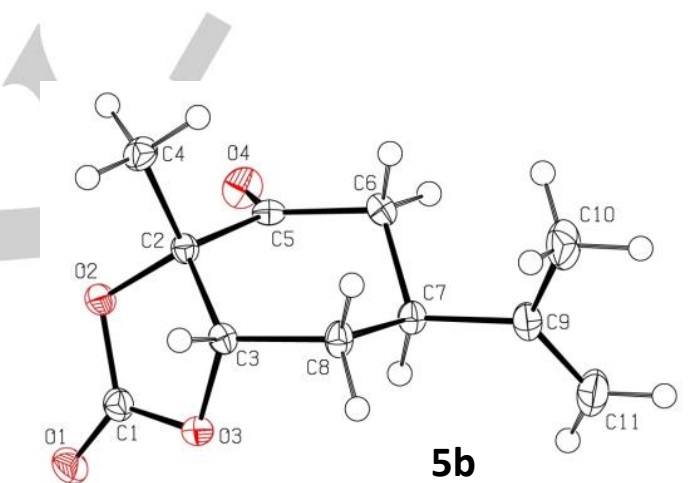

$5 \mathbf{b}$
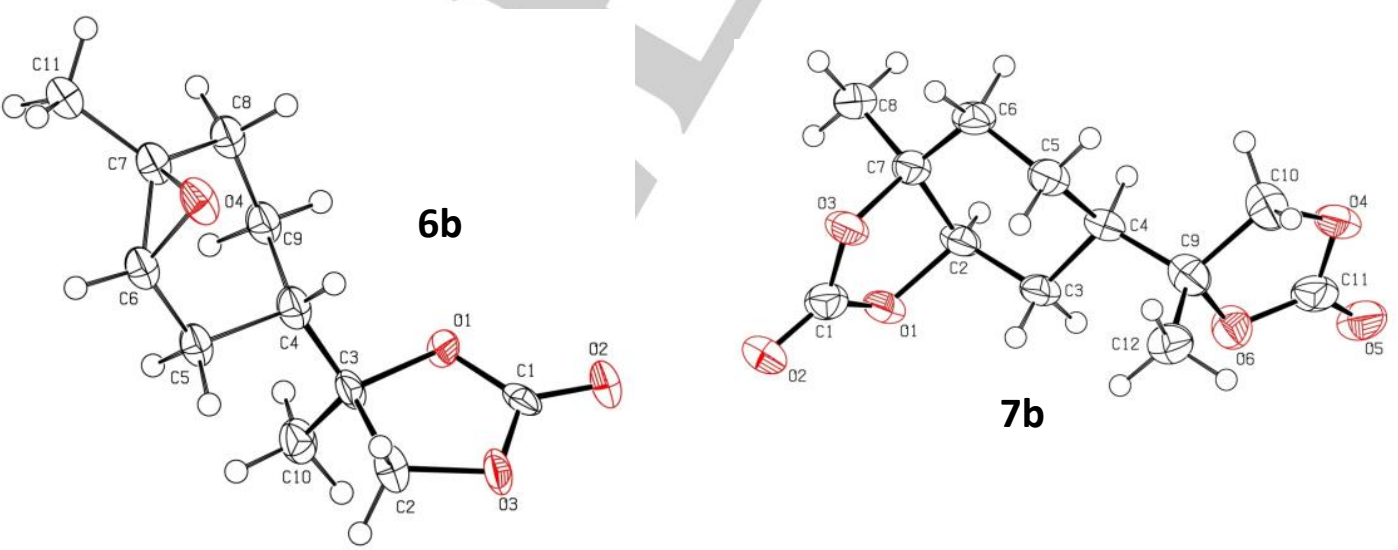

$7 b$

Figure 4. X-ray molecular structures for terpene carbonates trans-2b, cis-5b, $\mathbf{6 b}$ and trans-7b with the adopted numbering scheme. Selected bond lengths $(\AA)$ and angles (ㅇ) for $\mathbf{2 b}$ : $\mathrm{C}(2)-\mathrm{O}(2)=1.221(8), \mathrm{C}(2)-\mathrm{O}(1)=1.326(8), \mathrm{C}(2)-\mathrm{O}(3)=1.344(7)$; $\mathrm{O}(2)-\mathrm{C}(2)-\mathrm{O}(3)=123.1(7)$, $\mathrm{O}(1)-\mathrm{C}(2)-\mathrm{O}(3)=112.8(5)$; $\mathrm{Selected}$ data for $5 \mathbf{b}$ : $\mathrm{C}(1)-\mathrm{O}(1)=1.200(2), \mathrm{C}(1)-\mathrm{O}(2)=1.350(2), \mathrm{C}(1)-\mathrm{O}(3)=1.338(2) ; \mathrm{O}(2)-\mathrm{C}(1)-\mathrm{O}(3)=111.73(14), \mathrm{O}(1)-\mathrm{C}(1)-\mathrm{O}(2)=123.53(17)$; $\mathrm{Selected}$ data for $6 \mathbf{b}: \mathrm{C}(1)-\mathrm{O}(1)=$ $1.330(7), \mathrm{C}(1)-\mathrm{O}(2)=1.197(7), \mathrm{C}(1)-\mathrm{O}(3)=1.333(8), \mathrm{C}(6)-\mathrm{O}(4)=1.448(9) ; \mathrm{O}(1)-\mathrm{C}(1)-\mathrm{O}(3)=112.6(5), \mathrm{O}(1)-\mathrm{C}(1)-\mathrm{O}(2)=124.5(7) ; \mathrm{Selected}$ data for $7 \mathrm{~b}: \mathrm{C}(1)-\mathrm{O}(1)$ $=1.336(7), \mathrm{C}(1)-\mathrm{O}(2)=1.474(6), \mathrm{C}(1)-\mathrm{O}(3)=1.354(7), \mathrm{C}(11)-\mathrm{O}(4)=1.362(7), \mathrm{C}(11)-\mathrm{O}(5)=1.182(8), \mathrm{C}(11)-\mathrm{O}(6)=1.332(7) ; \mathrm{O}(1)-\mathrm{C}(1)-\mathrm{O}(3)=111.3(5), \mathrm{O}(1)-\mathrm{C}(1)-$ $\mathrm{O}(2)=124.6(5), \mathrm{O}(4)-\mathrm{C}(11)-\mathrm{O}(6)=110.7(6), \mathrm{O}(4)-\mathrm{C}(11)-\mathrm{O}(5)=124.0(6)$. 
Table 2. Screening and optimization of reaction conditions in the coupling of acyclic terpene-based epoxides $\mathbf{9 a}-\mathbf{1 4 a}$ and $\mathrm{CO}_{2}$ to afford their cyclic carbonate products $\mathbf{9 b}-\mathbf{1 4 b}$. $^{[\mathrm{a}]}$ Note that the commercial olefinic, terpene precursors are drawn together with their epoxidized derivatives.

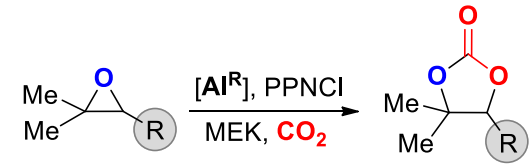

9b-14b (CC)<smiles>C=C(C)C(C)(O)Br</smiles>

$9 c-14 c$ (AA)<smiles>[R]C(=O)C(C)C</smiles>

9d-14d (K)<smiles>[R3]C(C)(OC)C(C)(C)OC(C)(C)C</smiles>

9e-14e (PE)<smiles>CC(=O)OCCC(C)CCC1OC1(C)C</smiles><smiles>C=CC(C)(CCC(C)=O)OC(C)=O</smiles><smiles>CC(=O)CCCC(C)=CCOC(C)=O</smiles>
geranyl acetate<smiles>CCC(CCC1OC1C)/C(C)=C\COC(C)=O</smiles>

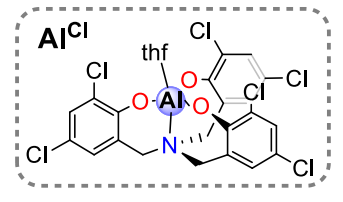<smiles></smiles>

myrcene

2,2,3-trimethyloxirane

\begin{tabular}{|c|c|c|c|c|c|c|c|c|c|c|c|}
\hline Entry & Substrate & $\begin{array}{l}\text { Cat } \\
\text { [mol\%] }\end{array}$ & $\begin{array}{l}\text { PPNCl } \\
\text { [mol\%] }\end{array}$ & $\begin{array}{l}p\left(\mathrm{CO}_{2}\right) \\
{[\mathrm{MPa}]}\end{array}$ & $\begin{array}{c}\mathrm{T} \\
{\left[{ }^{\circ} \mathrm{C}\right]}\end{array}$ & $\begin{array}{c}\mathrm{t} \\
{[\mathrm{h}]}\end{array}$ & $\begin{array}{l}\text { Epoxide } \\
{[\%]^{[b]}}\end{array}$ & $\begin{array}{c}\mathrm{AA} \\
{[\%]^{[b]}}\end{array}$ & $\begin{array}{c}\mathrm{K} \\
{[\%]^{[b]}}\end{array}$ & $\begin{array}{c}\mathrm{CC} \\
{[\%]^{[b]}}\end{array}$ & $\begin{array}{c}\mathrm{PE} \\
{[\%]^{[b]}}\end{array}$ \\
\hline 1 & $9 a$ & $\mathrm{Al}^{\mathrm{Cl}}, 1.0$ & 3.0 & 1.0 & 70 & 66 & 7 & 6 & 9 & 31 & 21 \\
\hline 2 & $9 a$ & - & 3.0 & 1.0 & 70 & 66 & 57 & 2 & $<1$ & 17 & 8 \\
\hline 3 & $9 a$ & $\mathrm{Al}^{\mathrm{Cl}}, 1.0$ & 3.0 & 1.0 & 85 & 66 & 22 & 5 & 3 & 20 & 35 \\
\hline $4^{[c]}$ & $9 a$ & $\mathbf{A l}^{\mid \mathrm{Cl}}, 1.0$ & 3.0 & 1.0 & 85 & 66 & $<1$ & 12 & 14 & 52 & 24 \\
\hline 5 & $9 a$ & - & 3.0 & 1.0 & 85 & 66 & 17 & 19 & 7 & 19 & 2 \\
\hline 6 & $9 a$ & $\mathbf{A l}^{\mid C I}, 1.0$ & 3.0 & 3.0 & 70 & 66 & 16 & $<1$ & $<1$ & 45 & 22 \\
\hline 7 & $9 a$ & $\mathrm{Al}^{\mathrm{I} I}, 1.0$ & 3.0 & 4.0 & 70 & 66 & 23 & $<1$ & $<1$ & 36 & 36 \\
\hline 8 & $9 a$ & - & 3.0 & 4.0 & 70 & 66 & 27 & 2 & $<1$ & 15 & 23 \\
\hline $9^{[c]}$ & $9 a$ & $\mathbf{A l}^{|c|}, 1.0$ & 3.0 & 4.0 & 85 & 66 & 3 & 7 & 7 & 56 & 28 \\
\hline 10 & $14 a$ & $\mathbf{A l}^{\mathrm{tBu}}, 1.0$ & 3.0 & 1.0 & 85 & 24 & 23 & 2 & 6 & 51 & 13 \\
\hline 11 & $14 a$ & $\mathbf{A l}^{\mid C l}, 1.0$ & 3.0 & 1.0 & 85 & 24 & 40 & 2 & 9 & 31 & 16 \\
\hline $12^{[c]}$ & $10 a$ & $\mathbf{A l}^{\mid \mathrm{Cl}}, 1.0$ & 3.0 & 4.0 & 85 & 66 & 8 & 2 & 8 & 47 & 35 \\
\hline $13^{[c]}$ & $11 a$ & $\mathbf{A l}^{\mid \mathrm{Cl}}, 1.0$ & 3.0 & & 85 & 66 & 5 & 5 & 7 & 61 & 16 \\
\hline $14^{[c]}$ & $12 a$ & $\mathbf{A l}^{\mid \mathrm{I}}, 1.0$ & 3.0 & 4.0 & 85 & 66 & 3 & 4 & 3 & 71 & 9 \\
\hline $15^{[\mathrm{d}]}$ & $13 a$ & $\mathbf{A l}^{\mid \mathrm{Cl}}, 1.0$ & 3.0 & 1.0 & 85 & 66 & $<1$ & 15 & 16 & 19 & 30 \\
\hline
\end{tabular}

[a] Reactions conditions: substrates $9 \mathrm{a}-\mathbf{1 4 a}(2.5 \mathrm{mmol}), \mathrm{MEK}$ (methylethyl ketone, $0.5 \mathrm{~mL}$ ), pressure/time/temperature and catalyst/co-catalyst loadings indicated. [b] NMR yields from ${ }^{1} \mathrm{H}$ NMR analysis using mesitylene as internal standard; for the use of 9a: allylic alcohol (AA) peak at $\delta=4.93 \mathrm{ppm}$ (septet) and 4.84 ppm (quintet), ketone (K) peak at $\delta=2.61 \mathrm{ppm}$ (quintet), epoxide at $\delta=2.68 \mathrm{ppm}$ (triplet), cyclic carbonate (CC) peak at $\delta=4.20 \mathrm{ppm}$ (multiplet) and oligo/polyether peak in the region $\delta=3.3-3.8 \mathrm{ppm}$. [c] Substrate amount was $5.0 \mathrm{mmol}$. [d] The ${ }^{1} \mathrm{H}$ NMR spectrum of the crude mixture showed apart from the CC product $13 \mathrm{~b}$ a number of peaks in the region $5.0-5.5$ ppm attributed to unknown olefin-containing by-products.

resulting in the almost exclusive formation of trans-4b from transLO in $43 \%$ isolated yield. The proposed trans-connectivity pattern in $\mathbf{2 b}$ was confirmed by NMR analysis and further substantiated by X-ray diffraction (see Figure 4). As far as we know, Figure 4 represents the first structurally characterized terpene based carbonates. The trans nature of carbonate $\mathbf{2 b}$ enforces the idea that these conversions occur with complete retention of configuration as would be expected from a double inversion pathway. ${ }^{[9 b, 12 c]}$ Interestingly, we previously observed that cis-LO reacts faster than its trans isomer in copolymerization reactions 
resulting in an almost exclusive formation of a trans configured copolymer (i.e. a formal inversion occurred). Conversely, at higher temperatures $\left(85^{\circ} \mathrm{C}\right)$ cyclic carbonate formation starting from the trans isomer seems to be the favoured process (cf., formation of trans-2b and trans-4b, Figure 3 ). The observed requisite for higher reaction temperatures in the case of cyclic carbonate formation from LO is in agreement with the higher computed kinetic barriers compared with the corresponding copolymerization process. ${ }^{[12 a]}$

Coupling between $\mathrm{CO}_{2}$ and other (bi)cyclic terpene oxides (including carvone oxide, limonene diepoxide and menthene oxide) exhibited a similar reactivity giving the respective terpene (mono)carbonates $\mathbf{5 b}, \mathbf{6 b}$ and $\mathbf{8 b}$ in $\mathbf{4 5 - 5 2 \%}$ yield and high chemo-selectivity. ${ }^{[16]}$ We also attempted to optimize the synthesis of limonene bis-carbonate $\mathbf{7 b}(27 \%)$ using more forcing reaction conditions $\left(120^{\circ} \mathrm{C}\right)$ but at the cost of the chemo-selectivity. This is likely due to an observed increase of the viscosity of the reaction mixture during the reaction of limonene diepoxide, limiting the diffusion of $\mathrm{CO}_{2}$ towards the reactive centre; the presence of significant amounts of oligo/polyether product as determined by ${ }^{1} \mathrm{H}$ NMR is in line with this assumption (see Supporting Information for details). The molecular structures of terpene (bis)carbonates $\mathbf{2 b}, \mathbf{5 b}, \mathbf{6 b}$ and $\mathbf{7 b}$ were determined by X-ray crystallography and confirmed in all cases their proposed formulations. Notably, as far as we know, these X-ray analyses represent the first ones reported for this family of bio-based carbonates, and bis-carbonate $\mathbf{7 b}$ was for the first time isolated and fully characterized. ${ }^{[10 c]}$

Formation of Acyclic Terpene Carbonates. We next turned our focus on the formation of terpene carbonates based on acyclic scaffolds. Our investigation started with the epoxide derived from citronellyl acetate 9a (Table 2) using the optimal conditions developed for the synthesis of most of the bicyclic terpene carbonates (i.e., $85^{\circ} \mathrm{C}, 1.0 \mathrm{MPa}, 66 \mathrm{~h} ; 3.0 \mathrm{~mol} \% \mathrm{PPNCl}$ ) but using $\mathrm{Al}^{\mathrm{Cl}}(1 \mathrm{~mol} \%)$ as the Lewis acid. ${ }^{[17]}$ Whereas the conversion of $9 \mathrm{a}$ already proceeds at $70^{\circ} \mathrm{C}$ (entry 1 ) with a $31 \%$ NMR yield for the corresponding cyclic carbonate $\mathbf{9 b}$, at $85^{\circ} \mathrm{C}$ (entry 3 ) we unexpectedly observed a poorer outcome in terms of chemoselectivity. Increasing the scale of the reaction (entry 4) did result in further improvement, but a combination of the latter with a higher applied $\mathrm{CO}_{2}$ pressure (entries 6, 7 and 9; 3.0-4.0 MPa) gave slightly more satisfactory results observing formation of the corresponding cyclic carbonate in $56 \%$ NMR yield ( $51 \%$ isolated, Figure 5) while further suppressing by-product formation. Notably, the reaction performed with only the nucleophilic additive (PPNCl) proceeded with significantly lower efficiency (cf., entries 2 and 8).

It should be noted that the overall chemo-selectivity towards the carbonate $9 b$ was much poorer than the ones observed starting from the aforementioned bicyclic terpene oxides. ${ }^{[18]}$ Beside the formation of substantial amount of oligo/polyether (Table 2, entry $9,28 \% ; 9 \mathbf{e}$ ), ${ }^{[19]}$ the formation of two other sideproducts was noted. These side-products were isolated and fully characterized for the citronellyl acetate case (see Experimental Section and Supporting Information for details), and were unambiguously identified as an allylic alcohol (9c) and a ketone (9d), both arising from the rearrangement of the starting epoxide 9a (see Figure 6). The allylic alcohol 9c may arise from a phenolate-assisted rearrangement of the epoxide 9a; such conversions have precedence though are typically carried out with strong bases. ${ }^{[20]}$ Additionally, Lewis acid induced Meinwald type rearrangement of epoxides to ketones has been wellestablished. ${ }^{[21]}$

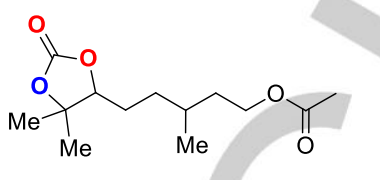<smiles>CC(=O)OCC(C)=C(C)CCC1OC(=O)OC1(C)C</smiles>

9b: Yield $51 \%, d r=51: 49 \quad$ 10b: Yield $46 \%$<smiles>C=CC(C)(CCC1OC(=O)OC1(C)C)OC(C)=O</smiles>

11b: Yield 61\%, $d r=51: 49$

12b: Yield 61\%
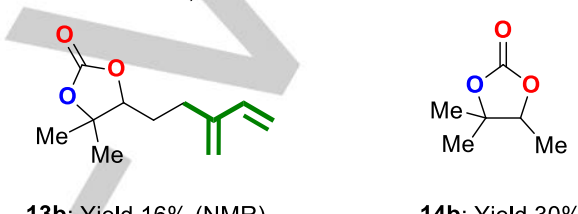

13b: Yield 16\% (NMR)

14b: Yield $30 \%$

Figure 5. Schematic structures of the terpene derived carbonates $\mathbf{9 b - 1 4 b}$, thei isolated yields after chromatographic purification and diastereo-isomeric ratios $(d r)$ for $\mathbf{9 b}$ and $\mathbf{1 1 b}$. For terpene carbonates $\mathbf{1 0 b}$ and $\mathbf{1 2 b}$ the amount of $(E)$ and $(Z)$ isomers, respectively, was $>98 \%$.

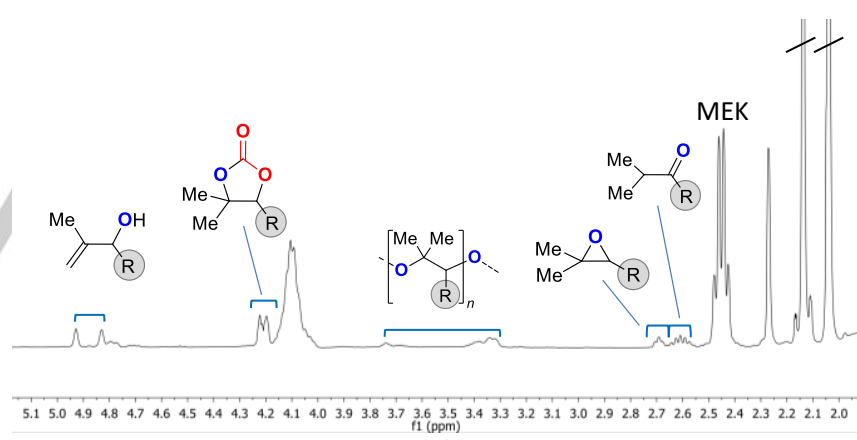

Figure 6. ${ }^{1} \mathrm{H}$ NMR trace $\left(\mathrm{CDCl}_{3}\right.$, region 2.0-5.1 ppm) for the crude product obtained in the conversion of terpene oxide $9 \mathrm{a}$ and the assigned peaks, MEK stands for methylethyl ketone. Note that the $\mathrm{R}$ group in the schematic figures represents a $-\mathrm{CH}_{2} \mathrm{CH}_{2} \mathrm{CH}(\mathrm{Me}) \mathrm{CH}_{2} \mathrm{CH}_{2} \mathrm{OAc}$ side chain. For a full NMR trace see the Supporting Information.

In order to rule out the possibility that the terpene scaffold itself induces the aforementioned side-product formation, we carried out the synthesis of the non-functionalized, tri-substituted cyclic carbonate 14b derived from trimethyloxirane 14a: in essence the same product distribution was observed (Table 2, entries 10 and 11, Figure 5) confirming that side-product formation does not depend on the nature of the terpene scaffold. Furthermore, the less polar and more volatile nature of $14 a$ seem 
to influence the course of the coupling reaction as for this substrate the use of the $\left[\mathbf{A l}^{\mathrm{tBu}}\right]$ complex gave better results (Table 2 , entries 10 and 11).

Having determined the optimized conditions for the preparation of acyclic terpene carbonates (Table 2, entry 9) we then extended the scope of these transformations to terpene oxides 10a-13a which were converted into the respective cyclic carbonate products 10b-13b (entries 12-15). In general, apart from the desired carbonate products, similar distributions of sideproducts (allylic alcohol, ketone and oligo/polyether) were observed, together with small amounts of the starting material. The desired cyclic carbonate products were conveniently isolated by column purification of the crude mixtures in yields of up to $61 \%$ (for 11b and 12b; Figure 5). Notably, using a myrcene based scaffold (13b) led to the formation of a complex reaction mixture as other side reactions involving the conjugated double bonds occurred. Indeed, we were not able to isolate a pure sample of 13b using chromatographic separation as further degradation occurred during the purification step. It is well-known that isoprenes show good polymerization potential in the presence of Lewis acids ${ }^{[22]}$ and this subunit is also present in 13b (highlighted in green). Thus, it seems reasonable to assume that further impurities to the ones reported in Table 2 (entry 15) may also be ascribed to oligo-myrcene species (see Supporting Information for details) resulting from diene activation catalysed by complex B.

The significant by-product formation generally observed for the synthesis of acyclic terpene carbonates $\mathbf{9 b - 1 4 b}$ as opposed to the chemo-selective formation of bicyclic carbonate structures $\mathbf{1 b}-\mathbf{5 b}$ and $\mathbf{8 b}$ can be explained taking into account the different transformations involving the metal-alkoxide intermediate formed after nucleophilic ring-opening of the epoxide group. ${ }^{[23]}$ In particular, it should be noted that polyether formation remains a competitive process even for $\mathrm{CO}_{2}$ coupling reactions with acyclic substrates carried out at higher pressure $(4.0 \mathrm{MPa}$, cf. entry 4 and 9, Table 2). This observation suggests that, after initial coordination of the epoxide to the Lewis acid catalyst and subsequent nucleophile-assisted ring opening, acyclic substrates favour the insertion of an additional epoxide molecule rather than $\mathrm{CO}_{2}$ insertion. This behaviour can be ascribed to the nature of the Lewis acid catalyst employed: in particular, a chloride-substituted $\mathrm{Al}\left(\right.$ aminotriphenolate) complex (i.e., $\mathbf{A l}^{\mathbf{C l}}$ ) was used with acyclic substrates $\mathbf{9 a - 1 4 a}$. Previous studies have shown that this $\mathbf{A l}{ }^{\mathrm{Cl}}$ complex combined with $\mathrm{NBu}_{4} \mathrm{l}$ is a highly active binary catalyst for terminal epoxide/ $\mathrm{CO}_{2}$ conversion into cyclic carbonates. Detailed computational and kinetic studies supported the view that $\mathrm{CO}_{2}$ insertion into the initially formed Al-alkoxide bond is the ratelimiting step. ${ }^{[6 d]}$ Thus, the higher Lewis acidity of $\mathbf{A l}^{\mathrm{Cl}}$, when compared to $\mathbf{A l}^{\mathbf{t B u}}$, results in a relatively more stable Al-alkoxide intermediate with a lower nucleophilic character, thus making the $\mathrm{CO}_{2}$ insertion step slower. This former observation seems to corroborate with the modest chemo-selectivities attained in the synthesis of acyclic terpene carbonates $\mathbf{9 b}$ and $\mathbf{1 1 b}-\mathbf{1 4 b}$. As a result substantial oligo/polyether formation is noted.

In order to qualitatively assess the influence of the structure of the Al-complex on the overall selectivity, we decided to prepare terpene carbonate $9 \mathrm{~b}$ (based on citronellyl acetate) using the
$\mathbf{A l}^{\mathrm{tBu}}$ complex under the same conditions as reported in entry 9 (Table 2). Whereas the use of $\mathbf{A l}^{\mathrm{Cl}}$ gives rise to virtually full conversion of the starting epoxide $9 a(97 \%)$, significant formation of oligo/polyether $9 \mathrm{e}(28 \%)$ is also noted with a calculated chemoselectivity towards the carbonate $9 \mathrm{~b}$ of $57 \%$ (56\% NMR yield). Notably, the presence of $\mathbf{A}^{\mathbf{I}^{\mathrm{B} u}}$ results in lower conversion of epoxide 9 a $(71 \%)$ alongside with formation of a much lower amount of oligo/polyether (8\%) with an overall chemo-selectivity of $67 \%$ for carbonate $9 b$ ( $46 \%$ NMR yield).

In contrast, the use of $\mathbf{A l}^{\mathrm{tBu}}$ with bicyclic terpene oxides led to the chemo-selective formation of the respective terpene carbonates (Figure 3). This is in agreement with our former notion that this Lewis acidic complex is primarily involved at the initial stage of the coupling between the epoxide and $\mathrm{CO}_{2}$, as previously proposed for oxetane $/ \mathrm{CO}_{2}$ coupling reactions promoted by $\mathbf{A l}^{\mathrm{tBu}}{ }^{[24]}$ Upon formation of a metal hemi-carbonate intermediate, the metal-mediated formation of the cyclic carbonate is sterically disfavoured. This causes to release the hemi-carbonate from the coordination sphere of the metal following fast outer-sphere cyclization. The combined observed differences in chemoselectivity underline the importance of matching the reactivity and product selectivity features in the formation of terpene based cyclic carbonates.

\section{Conclusions}

In summary, we have developed the first general and effective route towards bio-based, cyclic carbonates derived from various terpene scaffolds. A binary catalyst comprising a Lewis acidic $\mathrm{Al}(\mathrm{III})$ complex and a nucleophilic additive (PPNCl) is able to mediate these challenging conversions with different degrees of chemo-selectivity: bicyclic terpene oxides were converted with high selectivity whereas the acyclic substrates showed inferior chemo-selectivity under comparable temperature/pressure conditions. The highly challenging nature of these conversions limit to some extend the isolated yields of the terpene carbonates (typically between 50-60\%), though the results shown herein offer a reference point for catalyst development to further optimize the reactivity/selectivity features of such processes. Our future activities therefore aim at improving these aspects by carefully designing suitable (aminophenolate) ligand scaffolds and selection of appropriate Lewis acid metals favouring $\mathrm{CO}_{2}$ insertion into the metal-alkoxide bond after nucleophilic activation of the epoxide substrate.

\section{Experimental Section}

\section{General Information}

${ }^{1} \mathrm{H},{ }^{13} \mathrm{C}\{1 \mathrm{H}\}$ and the 2D NMR spectra were recorded on a Bruker AV-300 AV-400 or AV-500 spectrometer using the residual solvent peak for calibration. Mass spectrometric analyses and X-ray diffraction studies were performed by the Research Support Group at the ICIQ (Tarragona). FT-IR measurements were carried out on a Bruker Optics FTIR Alpha spectrometer. Carbon dioxide was purchased from PRAXAIR and used without further purification. Solvents used in the synthesis of the 
complexes were dried using an Innovative Technology PURE SOLV solvent purification system.

\section{General Procedure for the Bicyclic Terpene Carbonates}

All reactions were performed in a $30 \mathrm{~mL}$ stainless steel reactor. As a typical experiment, $560.8 \mathrm{mg}(5.0 \mathrm{mmol})$ of 1 -methylcyclohexene oxide (1a) were introduced in the inner Teflon vessel of a $30 \mathrm{~mL}$ autoclave alongside with $34.7 \mathrm{mg}(0.05 \mathrm{mmol})$ of $\mathbf{A} \mathbf{I}^{\mathrm{tBu}}, 86.1 \mathrm{mg}(0.15 \mathrm{mmol})$ of PPNCl and $1.0 \mathrm{~mL}$ of methyl ethyl ketone (MEK). Three cycles of pressurization and depressurization of the reactor $\left(p \mathrm{CO}_{2}=0.5 \mathrm{MPa}\right)$ were performed, and the pressure was finally stabilized at $1.0 \mathrm{MPa}$. The reactor was heated to the required temperature $\left(T=85^{\circ} \mathrm{C}\right)$, and the mixture was then stirred for another $66 \mathrm{~h}$. Hereafter, the reaction was stopped and the autoclave was allowed to cool down by immersion in an ice bath for $1 \mathrm{~h}$ before venting. The reaction mixture was diluted in $2.0 \mathrm{~mL}$ of $\mathrm{CDCl}_{3}$ and a weighed quantity of mesitylene (typically around $10 \% \mathrm{~mol}$ with respect to the epoxide substrate) was added. A quantitative ${ }^{1} \mathrm{H}$ NMR determination was carried out on samples consisting of $100 \mu \mathrm{L}$ of this solution diluted with 0.5 $\mathrm{mL}$ of $\mathrm{CDCl}_{3}$. After concentration of the crude reaction mixture in vacuo, the cyclic carbonate product $\mathbf{1 b}$ (3a-methylhexahydrobenzo[d][1,3]dioxol2-one) was isolated upon purification through a short silica path using $\mathrm{CH}_{2} \mathrm{Cl}_{2}$ as eluent.

Data for 3a-methylhexahydrobenzo[d] [1,3]dioxol-2-one (1b): ${ }^{1} \mathrm{H}$ NMR (500 $\left.\mathrm{MHz}, 298 \mathrm{~K}, \mathrm{CDCl}_{3}\right): \delta=4.35\left(\mathrm{t},{ }^{3} \mathrm{~J}=4.1 \mathrm{~Hz}, 1 \mathrm{H}\right), 2.09-2.03(\mathrm{~m}, 1 \mathrm{H}), 1.85$ $1.80(\mathrm{~m}, 2 \mathrm{H}), 1.76-1.65(\mathrm{~m}, 2 \mathrm{H}), 1.56-1.49(\mathrm{~m}, 2 \mathrm{H}), 1.48(\mathrm{~s}, 3 \mathrm{H}), 1.38-1.27$ $(\mathrm{m}, 1 \mathrm{H}):{ }^{13} \mathrm{C}\left\{{ }^{1} \mathrm{H}\right\} \mathrm{NMR}\left(126 \mathrm{MHz}, 298 \mathrm{~K}, \mathrm{CDCl}_{3}\right): \delta=154.95,82.92,81.19$, 33.80, 26.01, 23.42, 20.52, 18.80; FT-IR (neat): $1771 \mathrm{~cm}^{-1}(\mathrm{C}=\mathrm{O})$; HRMS $\left(\mathrm{ESI}+, \mathrm{CH}_{3} \mathrm{OH}\right): \mathrm{m} / z$ calcd. $\left(\mathrm{C}_{8} \mathrm{H}_{12} \mathrm{O}_{3}\right): 179.0679(\mathrm{M}+\mathrm{Na})^{+}$; found: 179.0678

\section{General Procedure for the Acyclic Terpene Carbonates}

All reactions were performed in a $30 \mathrm{~mL}$ stainless-steel reactor. In a typical experiment, $1.07 \mathrm{~g} \quad(5.0 \mathrm{mmol})$ of 5-(3,3-dimethyloxiran-2-yl)-3methylpentyl acetate $(9 \mathbf{a})$ were introduced in the inner Teflon vessel of a $30 \mathrm{~mL}$ autoclave alongside with $34.8 \mathrm{mg}(0.05 \mathrm{mmol})$ of $\mathbf{A l}^{\mathrm{Cl}}, 86.1 \mathrm{mg}(0.15$ $\mathrm{mmol}$ ) of PPNCl and $1.0 \mathrm{~mL}$ of methyl ethyl ketone (MEK). Three cycles of pressurization and depressurization of the reactor $\left(p \mathrm{CO}_{2}=0.5 \mathrm{MPa}\right)$ were performed, after which the $\mathrm{CO}_{2}$ pressure was finally stabilized at 4.0 $\mathrm{MPa}$. The reactor was heated to the required temperature $\left(T=85^{\circ} \mathrm{C}\right)$, and the mixture was stirred for a further $66 \mathrm{~h}$. Hereafter the reaction was stopped and the autoclave was allowed to cool down completely by immersion in an ice bath for $1 \mathrm{~h}$ before venting. The reaction mixture was diluted with $2.0 \mathrm{~mL}$ of $\mathrm{CDCl}_{3}$ and a weighed quantity of mesitylene (typically around $10 \% \mathrm{~mol}$ with respect to the epoxide substrate) was added. A quantitative ${ }^{1} \mathrm{H}$ NMR determination was carried out on samples consisting of $100 \mu \mathrm{L}$ of this solution diluted with $0.50 \mathrm{~mL}$ of $\mathrm{CDCl}_{3}$. The cyclic carbonate product, 5-(5,5-dimethyl-2-oxo-1,3-dioxolan-4-yl)-3methylpentyl acetate $9 \mathrm{~b}$, was isolated in $51 \%$ yield by purification using column chromatography (support: $\mathrm{SiO}_{2}$, eluent: hexane/diethyl ether 1:1 $\left.\mathrm{v} / \mathrm{v}, \mathrm{R}_{f}=0.16\right)$. The by-products 6 -hydroxy-3,7-dimethyloct-7-en-1-yl acetate $9 \mathrm{c}\left(\mathrm{R}_{f}=0.26\right)$ and 3,7-dimethyl-6-oxooctyl acetate $9 \mathbf{d}\left(\mathrm{R}_{f}=0.18\right)$ were also isolated and fully characterized; the yields were 1 and $5 \%$, respectively.

Data for 5-(5,5-dimethyl-2-oxo-1,3-dioxolan-4-yl)-3-methylpentyl acetate (9b), mixture of diastereo-isomers with a dr of $51: 49:{ }^{1} \mathrm{H}$ NMR $(300 \mathrm{MHz}$, $\left.298 \mathrm{~K}, \mathrm{CDCl}_{3}\right): \delta=4.28-4.17(\mathrm{~m}, 1 \mathrm{H}), 4.17-4.00(\mathrm{~m}, 2 \mathrm{H}), 2.04(\mathrm{~s}, 3 \mathrm{H}), 1.81$. $1.48(\mathrm{~m}, 7 \mathrm{H}), 1.49(3 \mathrm{H}), 1.48-1.38(\mathrm{~m}, 1 \mathrm{H}), 1.37(\mathrm{~s}, 3 \mathrm{H}), 1.32-1.06(\mathrm{~m}, 1 \mathrm{H})$, $0.94\left(\mathrm{~d},{ }^{3} \mathrm{~J}=6.3 \mathrm{~Hz}, 3 \mathrm{H}\right) ;{ }^{13} \mathrm{C}\left\{{ }^{1} \mathrm{H}\right\}$ NMR $\left(101 \mathrm{MHz}, 298 \mathrm{~K}, \mathrm{CDCl}_{3}\right): \delta=$ $171.26,154.19,85.95,85.78,84.10,62.67,35.39,33.30,33.18,29.81$,
29.79, 26.83, 26.22, 21.34, 21.13, 19.30; FT-IR (neat): 1786 and $1733 \mathrm{~cm}$ ${ }^{1}(\mathrm{C}=\mathrm{O})$; HRMS $\left(\mathrm{ESI}+, \mathrm{CH}_{3} \mathrm{OH}\right): \mathrm{m} / z$ calcd. $\left(\mathrm{C}_{13} \mathrm{H}_{22} \mathrm{O}_{5}\right) 281.1359(\mathrm{M}+\mathrm{Na})^{+}$; found: 281.1362

Data for 6-hydroxy-3,7-dimethyloct-7-en-1-yl acetate (9c), mixture of diastereo-isomers with a $d r$ of $1: 1 .{ }^{1} \mathrm{H} \mathrm{NMR}\left(500 \mathrm{MHz}, 298 \mathrm{~K}, \mathrm{CDCl}_{3}\right): \delta=$ 4.93-4.87 (m, 1H), $4.81(\mathrm{~s}, 1 \mathrm{H}), 4.13-4.02(\mathrm{~m}, 2 \mathrm{H}), 4.00\left(\mathrm{t},{ }^{3} \mathrm{~J}=6.5 \mathrm{~Hz}, 1 \mathrm{H}\right)$, $2.02(\mathrm{~m}, 3 \mathrm{H}), 1.82(\mathrm{~s}, 1 \mathrm{H}), 1.69(\mathrm{~s}, 3 \mathrm{H}), 1.68-1.18(\mathrm{~m}, 6 \mathrm{H}), 1.13-1.01(\mathrm{~m}$ $1 \mathrm{H}), 0.94-0.84(\mathrm{~m}, 3 \mathrm{H}) ;{ }^{13} \mathrm{C}\left\{{ }^{1} \mathrm{H}\right\} \mathrm{NMR}\left(126 \mathrm{MHz}, 298 \mathrm{~K}, \mathrm{CDCl}_{3}\right): \delta=171.33$, $171.32,147.66,147.56,111.29,111.09,76.28,76.12,63.03,63.01,35.55$, $35.53,32.69,32.65,32.26,32.21,29.90,29.89,21.11,19.53,17.60$ 17.44; FT-IR (neat): $1737 \mathrm{~cm}^{-1}(\mathrm{C}=\mathrm{O})$; HRMS $\left(\mathrm{ESI}+, \mathrm{CH}_{3} \mathrm{OH}\right): \mathrm{m} / \mathrm{z}$ calcd. $\left(\mathrm{C}_{12} \mathrm{H}_{22} \mathrm{O}_{3}\right) 237.1461(\mathrm{M}+\mathrm{Na})^{+}$; found: 237.1457.

Data for 3,7-dimethyl-6-oxooctyl acetate (9d): ${ }^{1} \mathrm{H}$ NMR $(300 \mathrm{MHz}, 298 \mathrm{~K}$, $\left.\mathrm{CDCl}_{3}\right): \delta=4.09(\mathrm{~m}, 2 \mathrm{H}), 2.61(\mathrm{~m}, 1 \mathrm{H}), 2.46(\mathrm{~m}, 2 \mathrm{H}), 2.04(\mathrm{~s}, 3 \mathrm{H}), 1.74$ $1.33(\mathrm{~m}, 5 \mathrm{H}), 1.09\left(\mathrm{~d},{ }^{3} \mathrm{~J}=6.9 \mathrm{~Hz}, 6 \mathrm{H}\right), 0.91\left(\mathrm{~d},{ }^{3} \mathrm{~J}=6.2 \mathrm{~Hz}, 3 \mathrm{H}\right) ;{ }^{13} \mathrm{C}\left\{{ }^{1} \mathrm{H}\right\}$ $\operatorname{NMR}\left(101 \mathrm{MHz}, 298 \mathrm{~K}, \mathrm{CDCl}_{3}\right): \delta=215.2,171.6,63.2,41.3,38.2,35.8$, 31.0, 30.0, 21.5, 19.7, 18.8, 18.7; FT-IR (neat): 1737, $1710 \mathrm{~cm}^{-1}(\mathrm{C}=\mathrm{O})$; HRMS $\left(\mathrm{ESI}+, \mathrm{CH}_{3} \mathrm{OH}\right): \mathrm{m} / \mathrm{z}$ calcd. $\left(\mathrm{C}_{12} \mathrm{H}_{22} \mathrm{O}_{3}\right) 237.1461(\mathrm{M}+\mathrm{Na})^{+}$; found: 237.1459.

\section{Crystallographic Studies}

The measured crystals were stable under atmospheric conditions; nevertheless they were treated under inert conditions immersed in perfluoro-polyether as protecting oil for manipulation. Data Collection: measurements were made on a Bruker-Nonius diffractometer equipped with an APPEX II 4K CCD area detector, a FR591 rotating anode with Mo Ka radiation, Montel mirrors and a Kryoflex low temperature device $(T=$ $-173^{\circ} \mathrm{C}$ ). Full-sphere data collection was used with $\omega$ and $\varphi$ scans Programs used: Data collection Apex2 V2011.3 (Bruker-Nonius 2008), data reduction Saint+Version 7.60A (Bruker AXS 2008) and absorption correction SADABS V. 2008-1 (2008). Structure Solution: SHELXTL Version 6.10 (Sheldrick, 2000) was used.[25] Structure Refinement: SHELXTL-97-UNIX VERSION.

\section{Crystallographic Data for $\mathbf{1 b}$}

$\mathrm{C}_{8} \mathrm{H}_{12} \mathrm{O}_{3}, M_{\mathrm{r}}=156.18$, monoclinic, $P 2(1), a=7.6622(8) \AA, b=6.4129(6)$ $\AA, c=7.7635(8) \AA \AA, \alpha=90^{\circ}, \beta=98.300(3)^{\circ}, \gamma=90^{\circ}, V=377.48(8) \AA^{3}, Z=$ 2, $\rho=1.374 \mathrm{mg} \cdot \mathrm{M}^{-3}, \mu=0.104 \mathrm{~mm}^{-1}, \lambda=0.71073 \AA, T=100(2) \mathrm{K}, F(000)$ $=168$, crystal size $=0.40 \times 0.20 \times 0.20 \mathrm{~mm}^{3}, \theta(\min )=2.651^{\circ}, \theta(\max )=$ $32.20^{\circ}, 3344$ reflections collected, 2037 reflections unique $\left(R_{\text {int }}=0.0282\right)$, $\mathrm{GoF}=1.063, R_{1}=0.0345$ and $w R_{2}=0.0868[I>2 \sigma(I)], R_{1}=0.0358$ and $\mathrm{w} R_{2}=0.0880$ (all indices), $\mathrm{min} / \mathrm{max}$ residual density $=-0.319 / 0.379\left[\mathrm{e} \cdot \AA^{-3}\right]$. Completeness to $\theta\left(32.20^{\circ}\right)=90.4 \%$. CCDC 1451773 .

\section{Crystallographic Data for $\mathbf{2 b}$}

$\mathrm{C}_{11} \mathrm{H}_{16} \mathrm{O}_{3}, M_{\mathrm{r}}=196.24$, monoclinic, $P 2(1), a=6.048(4) \AA, b=15.614(9) \AA$, $c=6.338(5) \AA, \alpha=90^{\circ}, \beta=117.776(16)^{\circ}, \gamma=90^{\circ}, V=529.5(6) \AA^{3}, Z=2$, $\rho=1.231 \mathrm{mg} \cdot \mathrm{M}^{-3}, \mu=0.088 \mathrm{~mm}^{-1}, \lambda=0.71073 \AA, T=100(2) \mathrm{K}, F(000)=$ 212 , crystal size $=0.20 \times 0.20 \times 0.20 \mathrm{~mm}^{3}, \theta(\min )=2.61^{\circ}, \theta(\max )=25.89^{\circ}$, 3756 reflections collected, 1719 reflections unique $\left(R_{\mathrm{int}}=0.1029\right)$, GoF $=$ 1.014, $R_{1}=0.0873$ and $w R_{2}=0.2090[I>2 \sigma(I)], R_{1}=0.1027$ and $\mathrm{w} R_{2}=$ 0.2162 (all indices), $\mathrm{min} / \mathrm{max}$ residual density $=-0.379 / 0.540\left[\mathrm{e} \cdot \AA^{-3}\right]$, flack parameter $x=0.7(10)$. Completeness to $\theta\left(25.89^{\circ}\right)=98.8 \%$. CCDC 1451771.

\section{Crystallographic Data for $5 b$}


$\mathrm{C}_{11} \mathrm{H}_{14} \mathrm{O}_{4}, M_{\mathrm{r}}=210.22$, orthorhombic, $P 2(1) 2(1) 2(1), a=6.8787(9) \AA, b=$ 7.5688(9) $\AA, c=20.495(3) \AA, \alpha=90^{\circ}, \beta=90^{\circ}, \gamma=90^{\circ}, V=1067.1(2) \AA^{3}$, $Z=4, \rho=1.309 \mathrm{mg} \cdot \mathrm{M}^{-3}, \mu=0.099 \mathrm{~mm}^{-1}, \lambda=0.71073 \AA, T=100(2) \mathrm{K}$, $F(000)=448$, crystal size $=0.40 \times 0.20 \times 0.20 \mathrm{~mm}^{3}, \theta(\min )=1.99^{\circ}, \theta(\max )$ $=30.60^{\circ}, 11222$ reflections collected, 3225 reflections unique $\left(R_{\text {int }}=\right.$ $0.0271), \mathrm{GoF}=1.078, R_{1}=0.0370$ and $w R_{2}=0.0928[I>2 \sigma(I)], R_{1}=$ 0.0418 and $\mathrm{w} R_{2}=0.1018$ (all indices), $\mathrm{min} / \mathrm{max}$ residual density $=$ $-0.204 / 0.314\left[e \cdot \AA^{-3}\right]$, flack parameter $x=-0.1(4)$. Completeness to $\theta\left(30.60^{\circ}\right)=98.7 \% . \operatorname{CCDC} 1451774$

\section{Crystallographic Data for 6b}

$\mathrm{C}_{11} \mathrm{H}_{16} \mathrm{O}_{4}, M_{\mathrm{r}}=212.24$, triclinic, $P-1, a=6.4255(11) \AA ., b=9.2997(16) \AA, c$ $=9.3869(15) \AA, \alpha=103.713(5)^{\circ}, \beta=94.235(5)^{\circ}, \gamma=103.972(5)^{\circ}, V=$ $523.67(15) \AA^{3}, Z=2, \rho=1.346 \mathrm{mg} \cdot \mathrm{M}^{-3}, \mu=0.102 \mathrm{~mm}^{-1}, \lambda=0.71073 \AA$, $T=100(2) \mathrm{K}, F(000)=228$, crystal size $=0.06 \times 0.04 \times 0.005 \mathrm{~mm}^{3}, \theta(\mathrm{min})$ $=2.26^{\circ}, \theta(\max )=25.44^{\circ}, 11714$ reflections collected, 1810 reflections unique $\left(R_{\text {int }}=0.0813\right)$, GoF $=2.226, R_{1}=0.1174$ and $w R_{2}=0.3344[l>$ $2 \sigma(I), R_{1}=0.1607$ and $\mathrm{w} R_{2}=0.3434$ (all indices), $\mathrm{min} / \mathrm{max}$ residual density $=-0.475 / 0.421\left[\mathrm{e} \cdot \AA^{-3}\right]$. Completeness to $\theta\left(25.44^{\circ}\right)=94.5 \%$. CCDC 1451772. Note that the very small size of the crystal resulted in poor quality crystal data; despite this, the atom connectivity patterns as proposed in Figure 4 could be confirmed.

\section{Crystallographic Data for $7 b$}

$\mathrm{C}_{12} \mathrm{H}_{16} \mathrm{O}_{6}, M_{\mathrm{r}}=256.25$, orthorhombic, $P 2(1) 2(1) 2(1), a=8.3285(17) \AA, b$ $=11.495(2) \AA ⿻ 12=12.522(3) \AA, \alpha=90^{\circ}, \beta=90^{\circ}, \gamma=90^{\circ}, V=1198.8(4) \AA^{3}$, $Z=4, \rho=1.420 \mathrm{mg} \cdot \mathrm{M}^{-3}, \mu=0.114 \mathrm{~mm}^{-1}, \lambda=0.71073 \AA$. $T=100(2) \mathrm{K}$, $F(000)=544$, crystal size $=0.30 \times 0.10 \times 0.10 \mathrm{~mm}^{3}, \theta(\min )=2.41^{\circ}, \theta(\max )$ $=24.70^{\circ}, 4780$ reflections collected, 2006 reflections unique $\left(R_{\text {int }}=0.0751\right)$ GoF $=1.030, R_{1}=0.0625$ and $w R_{2}=0.1430[l>2 \sigma(I)], R_{1}=0.0922$ and $\mathrm{w} R_{2}=0.1624$ (all indices), $\mathrm{min} / \mathrm{max}$ residual density $=-0.245 / 0.316\left[\mathrm{e} \cdot \AA^{-3}\right]$. Completeness to $\theta\left(24.70^{\circ}\right)=99.2 \%$. CCDC 1451775 .

\section{Acknowledgements}

We thank ICIQ, ICREA, and the Spanish Ministerio de Economía y Competitividad (MINECO) through project CTQ- 2014-60419-R and the Severo Ochoa Excellence Accreditation 2014-2018 through project SEV-2013-0319. Dr. Noemí Cabello, Sofía Arnal and Vanessa Martínez are acknowledged for the mass analyses. G.F. kindly acknowledges financial support from the European Community through FP7-PEOPLE-2013-IEF project RENOVACARB (grant agreement no. 622587), C. M. is grateful to the Marie Curie COFUND action from the European Commission for co-financing a postdoctoral fellowship and M.S. thanks the Erasmus program of the EU for support.

Keywords: aluminium $\cdot$ biocarbonates $\cdot$ carbon dioxide $•$ homogeneous catalysis $\cdot$ terpenes

[1] a) M. Aresta, A. Dibenedetto, A. Angelini, Chem. Rev. 2014, 114, 1709 1742; b) M. Cokoja, C. Bruckmeier, B. Rieger, W. A. Herrmann, F. E. Kühn, F. E. Angew. Chem. Int. Ed. 2011, 50, 8510-8537; c) Q. Liu, L. Wu, R. Jackstell, M. Beller, Nat. Commun. 2015, 6, 5933; d) N. Kielland, C. J. Whiteoak, A. W. Kleij, Adv. Synth. Catal. 2013, 355, 2115-2138; e) T. Sakakura, K. Kohno, Chem. Commun. 2009, 1312-1330; f) M. Peters, B. Köhler, W. Kuckshinrichs, W. Leitner, P. Markewitz, T. E. Müller,
ChemSusChem 2011, 4, 1216-1240; g) D. R. Darensbourg, Chem. Rev. 2007, 107, 2388-2410.

[2] a) D. J. Darensbourg, Inorg. Chem. 2010, 49, 10765-10780; b) S. Klaus, M. W. Lehenmeier, C. E. Anderson, B. Rieger, Coord. Chem. Rev. 2011 255, 1460-1479; c) M. R. Kember, A. Buchard, C. K. Williams, Chem. Commun. 2011, 47, 141-163; d) X.-B. Lu, D. J. Darensbourg, Chem. Soc Rev. 2012, 41, 1462-1484; e) G. W. Coates, D. R. Moore, Angew. Chem Int. Ed. 2004, 43, 6618-6639.

[3] a) G. A. Olah, A. Goeppert, G. K. S. Prakash, J. Org. Chem. 2008, 74, 487-498; b) A. Bansode, A. Urakawa, J. Catal. 2014, 309, 66-70; c) W. Wang, S. Wang, X. Ma, J. Gong, Chem. Soc. Rev. 2011, 40, 3703-3727; d) P. G. Jessop, T. Ikariya, R. Noyori, Chem. Rev. 1995, 95, 259-270.

[4] For a selection: a) A. Tlili, X. Frogneux, E. Blondiaux, T. Cantat, Angew. Chem. Int. Ed. 2014, 53, 2543-2545; b) T. G. Ostapowicz, M. Schmitz, M. Krystof, J. Klankermayer, W. Leitner, Angew. Chem. Int. Ed. 2013, 52, 12119-12123; c) T. Mita, J. Chen, Y. Sato, Org. Lett. 2014, 16, 2200 2203; d) B. Yu, L.-N. He, ChemSusChem 2015, 8, 52-62; e) Y. Li, T. Yan, K. Junge, M. Beller, Angew. Chem. Int. Ed. 2014, 53, 10476-10480; f) D. Yu, S. P. Teong, Y. Zhang, Coord. Chem. Rev. 2015, 293-294, 279-291.

[5] For recent reviews: a) J. W. Comerford, I. D. V. Ingram, M. North, X. Wu, Green Chem. 2015, 17, 1966-1987; b) C. Martín, G. Fiorani, A. W. Kleij, ACS Catal. 2015, 5, 1353-1370; c) G. Fiorani, W. Guo, A. W. Kleij, Green Chem. 2015, 17, 1375-1389; d) P. P. Pescarmona, M. Taherimehr, Catal. Sci. Technol. 2012, 2, 2169-2187.

[6] High reactivity systems: a) Y. Qin, H. Guo, X. Sheng, X. Wang, F. Wang, Green Chem. 2015, 17, 2853-2858; b) T. Ema, Y. Miyazaki, S. Koyama Y. Yano, T. Sakai, Chem. Commun. 2012, 48, 4489-4491; c) C. J. Whiteoak, N. Kielland, V. Laserna, E. C. Escudero-Adán, E. Martin, A. W. Kleij, J. Am. Chem. Soc. 2013, 135, 1228-1231; d) C. J. Whiteoak, N Kielland, V. Laserna, F. Castro-Gómez, E. Martin, E. C. Escudero-Adán, C. Bo, A. W. Kleij, Chem. Eur. J. 2014, 20, 2264-2275.; e) J. Qin, P. Wang, Q. Li, Y. Zhang, D. Yuan, Y. Yao, Chem. Commun. 2014, 50, 10952-10955

[7] a) M. Cokoja, M. E. Wilhelm, M. H. Anthofer, W. A. Herrmann, F. E. Kühn ChemSusChem 2015, 8, 2436-2454; b) Q. He, J. W. O'Brien, K. A Kitselman, L. E. Tompkins, G. C. T. Curtis, F. M. Kerton, Catal. Sci. Technol. 2014, 4, 1513-1528; c) A. Tlili, E. Blondiaux, X. Frogneux, T. Cantat, Green Chem. 2015, 17, 157-168.

[8] Efficient recycling under mild reaction conditions: a) C. J. Whiteoak, A. H. Henseler, C. Ayats, A. W. Kleij, M. A. Pericàs, Green Chem. 2014, 16, 1552-1559; b) W. Desens, C. Kohrt, M. Frank, T. Werner, ChemSusChem 2015, 8, 3815-3822; c) M. North, B. Wang, C. Young, Energy Environ. Sci. 2011, 4, 4163-4170; d) S. Liang, H. Liu, T. Jiang, J. Song, G. Yang, B. Han, Chem. Commun. 2011, 47, 2131-2133.

[9] Successful systems have been communicated reporting ample substrate scope: a) V. Laserna, G. Fiorani, C. J. Whiteoak, E. Martin, E. EscuderoAdán, A. W. Kleij, Angew. Chem. Int. Ed. 2014, 53, 10416-10419; b) C.J. Whiteoak, E. Martin, E. Escudero-Adán, A. W. Kleij, Adv. Synth. Catal. 2013, 355, 2233-2239; c) C. Beattie, M. North, P. Villuendas, C. Young J. Org. Chem. 2013, 78, 419-426; d) C. J. Whiteoak, E. Martin, M. Martínez Belmonte, J. Benet-Buchholz, A. W. Kleij, Adv. Synth. Catal. 2012, 354, 469-476; For a seminal contribution: e) W. J. Kruper, D. V. Dellar, J. Org. Chem. 1995, 60, 725-727.

[10] As far as we know the only examples report the formation of limonene based carbonates, see: a) C. M. Byrne, S. D. Allen, E. B. Lobkovsky, G. W. Coates, J. Am. Chem. Soc. 2004, 126, 11404-11405; b) O Hauenstein, M. Reiter, S. Agarwal, B. Rieger, A. Greiner, Green. Chem. 2016, 18, 760-770; c) M. Bähr, A. Bitto, R. Mülhaupt, Green Chem. 2012 $14,1447-1454$.

[11] H. Zhang, H. B. Liu, J. M. Yue, Chem. Rev. 2014, 114, 883-898.

[12] For examples including either terpene or fatty acid based (poly)carbonates: a) L. Peña Carrodeguas, J. González-Fabra, F. Castro-Gómez, C. Bo, A. W. Kleij, Chem. Eur. J. 2015, 21, 6115-6122; For examples using renewable "fatty acid" based epoxides, see: b) M Alves, B. Grignard, S. Gennen, C. Detrembleur, C. Jerome, T. Tassaing, 
RSC Adv. 2015, 5, 53629-53636; c) J. Langanke, L. Greiner, W. Leitner, Green Chem. 2013, 15, 1173-1182; d) P. G. Parzuchowski, M. JurczykKowalska, J. Ryszkowska, G. Rokicki, J. Appl. Polym. Sci. 2006, 102, 2904-2914; e) M. Bähr, R. Mülhaupt, Green Chem. 2012, 14, 483-489; f) Y.-Y. Zhang, X.-H. Zhang, R.-J. Wei, B.-Y. Du, Z.-Q. Fan, G.-R. Qi, RSC Adv. 2014, 4, 36183-36188.

[13] a) R. Ciriminna, M. Lomeli-Rodriguez, P. Demma Carà, J. A. LopezSanchez, M. Pagliaro, Chem. Commun. 2014, 50, 15288-15296; b) N. J. van Zee, G. W. Coates, Angew. Chem. Int. Ed. 2015, 54, 2665 -2668.

[14] Recently, Schäffner et al. reported on the synthesis of bio-sourced cyclic carbonates and their use as alternative plasticizers, see: B. Schäffner, M Blug, D. Kruse, M. Polyakov, A. Köckritz, A. Martin, P. Rajagopalan, U. Bentrup, A. Brückner, S. Jung, D. Agar, B. Rüngeler, A. Pfennig, K Müller, W. Arlt, B. Woldt, M. Graß, S. Buchholz, ChemSusChem 2014, 7, 1133-1139.

[15] Higher reaction temperatures tended to create different phases in the reactor where an ideal mixing of the substrate, $\mathrm{CO}_{2}$ and catalys components was not possible leading to lower conversion levels.

[16] A larger scale reaction using $10 \mathrm{~g}(65.8 \mathrm{mmol})$ of cis/trans limonene oxide and $\mathrm{CO}_{2}(1.0 \mathrm{MPa})$ in a $45 \mathrm{~mL}$ stainless steel autoclave at $85^{\circ} \mathrm{C}$ for $66 \mathrm{~h}$ was also probed. Somewhat lower conversion (35\%) and isolated yield $(3.7 \mathrm{~g}, 29 \%)$ was obtained compared to formation of $4 \mathrm{~b}$ in Figure $3(43 \%$ isolated yield). We ascribe this to a lower $\mathrm{CO}_{2}$-to-substrate ratio inside the reactor; however, the result suggests that larger-scale synthesis of $\mathbf{4 b}$ is potentially feasible. See Supporting Information for more details.

[17] For the acyclic terpene oxide substrates we found that the use of the $\mathrm{Al}^{\mathrm{C}}$ complex provided the best combination of conversion and selectivity and therefore proceeded with this complex. Note that again MEK was used as solvent since the acyclic terpene oxides are viscous oils and a relatively high loading of $\mathrm{Al}^{\mathrm{Cl}}$ and the nucleophilic additive are required. The neat reaction between methyl cyclohexene oxide and $\mathrm{CO}_{2}($ Table 1 , entry 11 ; only $1 \%$ conversion) is further reason for considering the use of a solvent in these reactions.

[18] In some of the reactions we noted an imperfect mass balance by combining the molar amounts of cyclic carbonate, starting epoxide and by-products as reported in Table 2 . We observed that upon cooling the reaction mixture that under certain conditions up to $10-15 \%$ of epoxide remained in other sections of the reactor, i.e. not in the Teflon insert containing the reaction mixture. In a separate experiment we determined this amount by washing these sections following ${ }^{1} \mathrm{H}$ NMR analysis: this showed unambiguously the presence of the epoxide substrate.

[19] The formation of oligo/polyether side products is rationalized by the sluggish nature of these conversions while increasing the viscosity of the reaction mixture. As such the transport of $\mathrm{CO}_{2}$ towards the reactive center is hampered and becomes a limiting factor, and side reactions such as oligo/polyether formation become more significant.

[20] For allylic alcohol formation from epoxides using strong bases: a) R. P. Thummel, B. Rickborn, J. Org. Chem. 1971, 36, 1365-1368; b) M. J. Södergren, S. K. Bertilsson, P. G. Andersson, J. Am. Chem. Soc. 2000, $122,6610-6618$. The triphenolate ligand of the Al complex may act as a basic residue promoting relatively slow allylic alcohol formation.

[21] For Lewis acid catalyzed Meinwald rearrangement of epoxides see: a) J. R. Lamb, Y. Jung, G. W. Coates, Org. Chem. Front. 2015, 2, 346-349; A recent contribution showed the use of Al-catalysis as a means to rearrange internal epoxides to ketones, see: b) J. R. Lamb, M. Mulzer, A M. LaPointe, G. W. Coates, J. Am. Chem. Soc. 2015, 137, 15049-15054.

[22] a) M. L. Senyek, Isoprene Polymers in Encyclopedia of Polymer Science and Technology, John Wiley \& Sons, 2002. Please note that Lewis acid catalyzed Diels-Alder chemistry of myrcene has also been reported, refer to: b) D. Yin, C. Li, B. Li, L. Tao, D. Yin, Adv. Synth. Catal. 2005, 347, 137-142.

[23] For detailed mechanistic description of the key steps (epoxide ringopening, $\mathrm{CO}_{2}$ insertion and ring-closure) involved in organic carbonate formation using binary catalysts comprising a Lewis acid and a nucleophilic additive: a) F. Castro-Gomez, G. Salassa, A. W. Kleij, C. Bo, Chem. Eur. J. 2013, 19, 6289-6298; b) M. North, R. Pasquale, Angew. Chem. Int. Ed. 2009, 48, 2946-2948; Very recently, the formation of in situ prepared organic carbonates was mechanistically linked towards diastereo-selective conversions with a key role for the Lewis acid catalyst, see: c) W. Guo, V. Laserna, E. Martin, E. C. Escudero-Adán, A. W. Kleij, Chem. Eur. J. 2016, 22, 1722-1727.

[24] J. Rintjema, W. Guo, E. Martin, E. C. Escudero-Adán, A. W. Kleij, Chem. Eur. J. 2015, 21, 10754-10762.

[25] G. M. Sheldrick, SHELXTL Crystallographic System, version 6.10; Bruker AXS, Inc.: Madison, WI, 2000 


\section{Entry for the Table of Contents:}

\section{FULL PAPER}

Bioconversions: A general catalytic method for the challenging coupling between terpene oxides and $\mathrm{CO}_{2}$ has been developed furnishing bicyclic and acyclic bio-carbonates in appreciable yields. The chemoselectivity features of both types of carbonate syntheses was studied in detail, and the first crystallographic analyses of such terpene carbonate scaffolds are presented. The results pave the way for the use of terpenes as synthons towards new materials and fine chemicals.

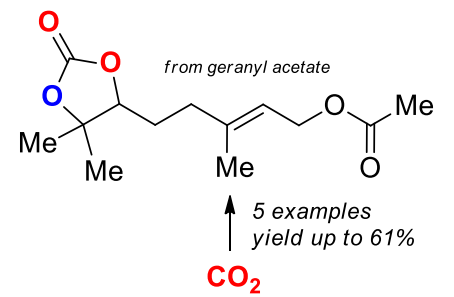

Giulia Fiorani, * Moritz Stuck, Carmen Martín, Marta Martínez Belmonte, Eddy Martin, Eduardo C. Escudero-Adán and Arjan W. Kleij ${ }^{*}$

$$
\begin{aligned}
& 8 \text { examples } \\
& \text { yield up to } 57 \%
\end{aligned}
$$

Catalytic Coupling of Carbon Dioxide with Terpene Scaffolds: Access to Challenging Bio-based Organic Carbonates 